\title{
Referral Demand of Patients in Pantai Cermin Public Health Center Langkat
}

\author{
Feti Novia Sari ${ }^{1}$, Zulfendri ${ }^{2}$, Sri Rahayu Sanusi ${ }^{3}$ \\ 1,2Department of Administration and Health Policy, Faculty of Public Health, Universitas Sumatera \\ Utara, Medan, Indonesia \\ 3Department of Reproduction Health, Faculty of Public Health, Universitas Sumatera Utara, Medan, \\ Indonesia \\ Email: fetinoviasari144@gmail.com
}

\begin{abstract}
:
In 2017, the number of referrals issued by Pantai Cermin health center to Langkat District Hospital was $\mathbf{1 7 . 7 \%}$ and the highest number in Langkat District. Referral cases more than $10 \%$ will increase hospital burden. This study aims to describe of referral cases at Pantai Cermin Health Center, Langkat. Aspect of referral type given 5 informants asked for referral to an internist, 2 informants asked for obstetricians, and one informant asked for referral to opthalmologist. Regarding who provided the referral, 6 informants stated that the referral was given by the doctor, and 2 informants stated that the referral was given by the midwife. In addition, the reason why the referral was given, 7 informants stated that the referral was given because the informant asked to be referred, and 1 informant stated that the referral was given because the equipment was not available at the public health center. Based on the results, it is recommended to pantai cermin health center to providing referral services in accordance with the applicable regulations and regularly monitoring of implementation of referrals system, and socialize to the community that referrals should be given according to the patient's medical need.
\end{abstract}

Keywords:

referral; public health center

\section{Introduction}

Community Health Centers is as one type of first-level health service facility have an important role in the national health system, especially the health care subsystem (RI Ministry of Health, 2014). In 2016, the number of Public Health Center in Indonesia reached 9,767 units in 34 provinces. For the Province of North Sumatra, the number of Public Health Center reached 571 units spread across 33 regencies and cities. Public Health Center is a firstlevel health facility (FKTP) that organizes public health efforts and first-level individual health efforts, with more emphasis on promotion and preventive efforts, to achieve the highest degree of public health. Public Health Center need to be reorganized to improve accessibility, affordability, and quality of service in order to increase the degree of the community and the success of the national social Insurance program (JKN).

National Health Insurance (JKN) is part of the National Social Insurance System (SJSN) organized by the Health Social Security Organizing Agency (BPJS) through a mandatory social health insurance mechanism. Every JKN participant has the right to obtain comprehensive health services that are provided in stages, effectively and efficiently by applying the principles of quality control and cost control based on medical indications. Therefore, to obtain these health services, the First Level Health Facility (FKTP) and the Advanced Referral Health Facility (FKTL) must implement a referral system. The public can make a referral to FKTL with the approval of the FKTP so that the FKTP's role is as a 
gatekeeper that is to optimize the role of the first level health facility in the health care system. Along with the commencement of the JKN as of 1 January 2014, all health insurance programs that have been implemented by the government such as Askes, Jamsostek, (Jamkesmas) were integrated into one Health Social Security Administering Agency (BPJS). BPJS is a health insurance provider body that manages individual health efforts (UKP) for all people in Indonesia. Health BPJS will collaborate with Health Service Implementers (PPK) at the first level and advanced level.

Health Insurance is a guarantee in the form of health protection so that participants receive health care benefits and protection in meeting basic health needs provided to everyone who has paid contributions or paid by the government (BPJS, 2014). Through JKN, the health service system is expected to increase the reach of health services to the community. One of the programs is to strengthen the first level Health Service Provider (PPK) as a gate keeper. In addition, the management of tiered health services needs to be strengthened so that the scope of health services is fair, quality and equitable. Public Health Center as one of the FKTP that provides health services to the community has a very strategic role in accelerating the improvement of community health status. Therefore Public Health Center are required to provide quality services that satisfy patients according to established standards and can reach all levels of society.

However, there are many problems that occur in FKTP namely the high ratio of referrals from FKTP to FKTL. National BPJS Health data shows that, in the first quarter of 2016 there were 14,619,528 visits in first level health facilities. From these data 2,236,379 visits were referred from primary care to secondary service levels and 214,706 visits were nonspecialist referrals which meant that they should not need to be referred and could be completed at first-level health facilities. Problems with the referral system not only refer to non-specialists but also the incomplete filling of forms. Pre referral communication that is no less important, is also not optimally implemented (Zuhrawardi, 2007). According to the director of BPJS, ideally only $10 \%$ of patients are referred to secondary services from 155 diagnoses of the disease, but to date the number of referrals to secondary services has reached $15.3 \%$.

First Level Health Facilities (FKTP) are Public Health Center, Pratama clinics, physician practices, dentist practices, Pratama clinics or equivalent and class D pratama hospitals or equivalent. Whereas those included in the second and third level health care facilities (Advanced Referral Health Facilities) are the main clinic, General Hospital and Special Hospital. Based on the classification of hospitals, the General / Special Hospital Class $\mathrm{C}$ and B can be categorized as Second Level Health Services (Secondary) and General / Special Hospital Class A or General / Special Hospital Class B which is the center of medical education can be categorized as Third Level Health Services (Tertiary) (Permenkes RI No. 001 of 2012). Health services in Indonesia are implemented in stages, starting with basic health services by first-level health facilities. Second-level health services can only be provided upon referral from first-level health services. Third-level health services can only be provided on reference to second-level or first-level health services, except in emergencies (Permenkes RI No. 001 of 2012).

In the JKN era, Public Health Center was expected to be able to handle 155 disease diagnoses in accordance with General Physician Competencies that could be handled at FKTP, so JKN participants no longer needed to go directly to the hospital, because even FKTP could be handled. But do not rule out the possibility of these cases can immediately go 
to the hospital by considering the Time (duration of the disease), Age (patient age), Complication (complications of the disease / level of difficulty), Comorbidity (concomitant disease), and Condition (condition of the facility health). Medical cases that can be resolved completely in FKTP are, primary service cases that refer to the competence of general practitioners, medical cases that require initial treatment before referral is made; and medical cases included in the BPJS Health Referral Program such as cases of Hypertension, Diabetes Mellitus (diabetes), asthma, Chronic Obstructive Pulmonary Disease (COPD), stroke, epilepsy, schizophren, Lupus Erythematosus (SLE) and Heart (BPJS Info Health) 2014 XI Edition).

Health services in Indonesia are implemented in stages, starting with basic health services by first-level health facilities. Second-level health services can only be provided upon referral from first-level health services. Third level health services can only be provided on reference to second or first level health services, except in emergencies (Permenkes RI No. 001 of 2012)

Based on data from BPJS Langkat District 2017, Pantai Cermin Health Center is the Public Health Center that provides the most referrals as many as 2124 specialist and nonspecialist referral cases with the number of BPJS participant visits as many as 12,873 people, then followed by Tanjung Langkat Health Center with a total of 1989 specialist and nonspecialist referral cases with the number of BPJS participant visits is 13952. Public Health Center that provided the least number of specialist and non-specialist referrals was the Stabat Public Health Center with a total of 1231 referral cases with 9683 BPJS participant visits. If the ratio is calculated, then the three Public Health Center above the reference point ratio above 10\%. The referral ratio recommended by the BPJS is below 10\% (BPJS, 2015). Thus, if the referral ratio of Pantai Cermin Health Center is calculated at $16.4 \%$, Tanjung Langkat Health Center at $14.25 \%$, and Stabat Health Center at $12.7 \%$.

\section{Research Method}

This type of research is a descriptive study using qualitative methods. Informants in this study were staff, doctors, heads and JKN participant patients at Pantai Cermin Public Healt Center (Public Health Center). Data collection methods are carried out by collecting primary data obtained directly from informants using questionnaires and secondary data obtained from library studies and document review. Document review is carried out to compare the results of interviews with data such as reference data, and other documents used in relation to the implementation of referrals at Public Health Center. Primary data that the author has obtained from interviews and secondary data is then processed and presented in descriptive form in textual form.

\section{Discussion}

The results of the study showed that based on the statement of the informant regarding the availability of health workers in Pantai Cermin Health Center, it was sufficient and in accordance with the established health workforce standards. Health workers are also ready to provide services to the community. However. According to the head of administration, in carrying out their duties there are still officers who work not in accordance with their main tasks and functions, such as midwives who work in the pharmacy section and work in the card room and officers are less cooperative. The attitude of health workers becomes the dominant factor which will affect the reuse of health services in Public Health 
Center, so that good health care attitudes need to be owned by health workers and be a concern towards prime health services (Wulandari and Anhari, 2016).

Based on the research results it is known that health workers and the reasons why choosing Pantai Cermin Health Center as the first level health facility is that the health service at Pantai Cermin Health Center is already good and the reason for choosing Pantai Cermin Health Center is because the patient has been registered at Pantai Cermin Health Center as the first level health facility. According to Minister of Health Regulation No. 75 of 2014 concerning Public Health Center, the minimum standard of health workers in rural areas is as many as 27 health workers and at Pantai Cermin Public Health Center there are as many as 48 health workers.

The role of health workers, especially medical personnel in referring patients, will determine the implementation of patient referrals to run optimally. Aspects seen from health workers in the implementation of JKN participant patients referring to the quantity of health workers and the readiness of health workers.

Based on research results at Pantai Cermin Health Center there are 48 health workers including primary service doctors or doctors, dentists, nurses, midwives, public health workers, environmental health workers, medical laboratory technology experts, nutritionists, pharmaceutical personnel, administrative personnel, and Workers, then, it can be said that the number of health workers in Pantai Cermin Health Center has been fulfilled because it meets the standards set by the government through the attachment to Permenkes No. 75 of 2014 concerning Public Health Center, the standard part of Public Health Center workforce.

Based on the results of research conducted that facilities or medical equipment facilities at Pantai Cermin Health Center in the implementation of the referral obtained information that the availability of facilities and infrastructure at Pantai Cermin Health Center was sufficient in providing health services and there were referral facilities such as ambulances, but according to several informants stating that the facility facilities health at the Pantai Cermin health center is still inadequate because there are tools that are not functioning and are still being repaired so that if the patient cannot be treated due to the unavailability of tools then the doctor will give a referral.

Information was obtained that at Pantai Cermin Health Center does not have advanced facilities and if the equipment at Public Health Center is not available in handling patients, patients will be referred. Based on observations it can be seen that in Pantai Cermin Health Center shows that of the 67 standard items of facilities and infrastructure recommended for first-level services there are 34 items that can be fulfilled by Public Health Center. Therefore, the availability of medical devices in Pantai Cermin Health Center is not sufficient and does not meet the standards of medical devices listed in the attachment to Permenkes No. 75 of 2014 concerning Public Health Center part of Public Health Center equipment requirements in the public inspection room.

The results of research on the availability of medicines at Pantai Cermin Health Center in the implementation of referrals to patients participating in the national health insurance explained by the managers of Pantai Cermin Health Center, obtained information that the availability of medicines available at Pantai Cermin Health Center in providing health services is fairly enough, ever a drug vacancy occurs at Pantai Cermin Health Center so similar drugs will be given. However, according to one informant, the drugs available at Pantai Cermin Public Health Center still do not meet the national formulary standards because there are still 
drugs that are not available such as CTM and dexamethasone drugs as a result of the patient's needs at Pantai Cermin Public Health Center.

Information was obtained that the patients had never bought drugs outside of Public Health Center and if the drugs were not available at Public Health Center, the patients stated that they were willing to buy drugs outside Public Health Center.

According to the results of observations made by researchers regarding the availability of drugs in Pantai Cermin Health Center referring to the Decree of the Minister of Health of the Republic of Indonesia Number HK 02.02/Menkes/523/2015 Concerning the National Formulary in First Level Health Facilities, shows that of 240 types of drugs that should be available at Public Health Center, available at Pantai Cermin Public Health Center there are 78 types of drugs available at Pantai Cermin Health Center, so the drugs available at Pantai Cermin Health Center are still inadequate and do not meet national formulary standards in first level health facilities as listed in the Decree of the Minister of Health of the Republic of Indonesia Number HK 02.0/Menkes/523/2015 concerning the National Formulary in First Level Health Facilities.

Based on observations of researchers who saw patients who forced to get a referral because there is still community suggestion if treatment at the hospital will recover from treatment at the health center. Patients who are included in the 144 diagnoses but have complications such as gastritis plus heart disease plus bronchitis will usually be referred by a doctor. The high number of referrals at Pantai Cermin Health Center is because patients are asking for reconciliation and complications of patient's illness. According to Alawi et al (2015), the optimal utilization of Public Health Center is due to the low trust of the community towards Public Health Center. In addition, the community also has a stigma about health services, which are bad / negative assumptions related to matters relating to health services received, especially Public Health Center (Wijono, 2010).

Based on the results of research in Pantai Cermin Health Center with in-depth interviews of JKN participants who were referred on the basis of the disease and reasons for requesting referrals, namely on referrals given by doctors because patients who need specialist treatment and on patients referred because of a patient's condition that has not healed and has recovered repeatedly went to the health center.

According to Gulo (2015) the public could not avoid the habit that occurred in previous years as evidenced by Botombawo Public Health Center. Many patients still asked to be referred directly to the hospital on the grounds that the Public Health Center was incomplete either from their doctors or the availability of medicines that were still lacking.

Based on the information received, the informant's statement regarding the flow of referral implementation at Pantai Cermin Health Center was found that the referral was carried out in stages and in accordance with the flow and had followed technical instructions from BPJS. Many patients ask for referrals because of their lack of understanding of the flow of referral implementation in the era of national health insurance. Patients who do not understand how the referral system was in the JKN era and there are still many patients who think that Public Health Center can issue referral letters to the hospital because it is their right even though the disease can still be handled at the Public Health Center.

According to Zuhrawardi (2007) in his study said that doctors in principle cannot refuse if a patient insists on requesting an outpatient referral even though it is not supported 
by medical indications. Generally patients who request outpatient referrals on their own initiative without any medical indication and have backgrounds ranging from high school to above. The reason patients ask for referrals in general is because the drugs given by the Public Health Center do not vary even though they suffer from different diseases.

In this case the community cannot avoid the habits that occurred in previous years proved at Pantai Cermin Health Center there are still many patients who ask to be referred directly to the hospital with the reason for faster recovery compared to treatment at the health center. The existence of some patients who do not get healed just by taking drugs when in fact patients do not need specialist health services is one factor in the high referral rates from FKTP to FKTL (Faulina et al, 2016).

Based on the results of the study, from the aspect of referral type stated that 5 informants who were JKN patients participating referred a specialist to internal medicine, 2 informants requested a referral for childbirth, and 1 informant requested a referral to an eye specialist. Regarding who gave the referral, 6 informants stated that the referral was given by the doctor and 2 informants said the referral was given by the midwife. Regarding the reason why the referral was given, 7 informants stated that the referral was given because the informant insisted on being referred and 1 informant stated that the referral was given because the tools were not available at the Public Health Center. According to Alawi et al (2015), the absence or incompleteness of medical devices can reduce and hinder the work of doctors in carrying out their work because medical devices are very important in their function to assist doctors in diagnosing and healing diseases. In addition, the availability of medical equipment facilities influences the implementation of the referral system (Kesumawati, 2012).

\section{Conclusion}

Based on research that has been done, it can be concluded that the availability of human resources has met in accordance with the competence of health workers, the availability of medical equipment facilities at the health center is still minimal, the type and amount of available drugs is still not fulfilled and unable to implement the referral flow in accordance with the referral service standards . Lack of patient knowledge of the referral system causes health workers experience overwhelmed in handling patient requests to be referred to a specialist.

\section{References}

Alawi, M., Purnawan, J., Siti, N.L., 2015. Analisis Faktor-Faktor yang Berhubungan dengan Tingginya Rujukan Kasus Non Spesialistik Pasien Jaminan Kesehatan Nasional pada Public Health Center di Kabupaten Sukabumi Tahun 2015. Jurnal Ekonomi Kesehatan Indonesia, 2(1): 17-23.

Faulina, A.C., Abu, K., Yennike, T.H., 2016. Kajian Pelaksanaan Sistem Rujukan Berjenjang dalam Program Jaminan Kesehatan Nasional (JKN) di UPT. Pelayanan Kesehatan Universitas Jember. Jurnal IKESMA, 12(2): 91-102.

Gulo, Martimanjaya. 2015. Analisis Rujukan Public Health Center Botombawo Kabupaten Nias Dalam Era Jaminan Kesehatan Nasional Tahun 2015. Skripsi. Fakultas Kesehatan Masyarakat Universitas Sumatera Utara.

Kementerian Kesehatan RI, 2014. Peraturan Menteri Kesehatan Nomor 28 Tahun 2014 tentang Pedoman Pelaksanaan Program Jaminan Kesehatan Nasional.

Keputusan Menteri Kesehatan Republik Indonesia Nomor HK 02.02/Menkes/523/2015 
Tentang Formularium Nasional Tentang Formularium Nasional di Fasilitas Kesehatan Tingkat Pertama.

Kesumawati. 2012. Analisis Pelaksanaan Rujukan Rawat Jalan Tingkat Pertama Peserta Askes Sosial PT. Askes Kantor Cabang Sukabumi tahhun 2012.

Permenkes No. 75 Tahun 2014 tentang Public Health Center bagian standar ketenagaan Public Health Center.

Wijono, S. 2010. Psikologi Industri dan Organisasi. Jakarta: Kencana

Wulandari, F.K., Anhari, A., 2016. Analisis Karakteristik dan Persepsi Pengguna Pelayanan terhadap Pemanfaatan Public Health Center Sebagai Gatekeeper di Dua Public Health Center Kota Bekasi Tahun 2016. Jurnal Ekonomi Kesehatan Indonesia, 2(1): 39-47. 